\section{Nytt legemiddel \\ reduserer mortalitet ved diabetes}

Et legemiddel som senker blodsukkeret er for første gang vist å redusere kardiovaskulær mortalitet hos pasienter med type 2-diabetes og etablert karsykdom. Studien er nylig publisert i The New England Journal of Medicine med en norsk lege som medforfatter.

Pasienter med type 2-diabetes har en redusert forventet levealder, primært pga. økt risiko for kardiovaskulær mortalitet. Til nå finnes det ikke kunnskapsgrunnlag for at blodsukkersenkning eller spesifikke blodsukkersenkende legemidler kan redusere denne risikoen blant personer med hjerteog karsykdom. Medikamentet empagliflozin senker blodsukkernivået gjennom å øke glukoseutskilling fra nyrene. Det har også andre metabolske effekter, bl.a. en reduksjon i blodtrykk og kroppsvekt.

I en multisenterstudie som startet i 2010 rekrutterte man over 7000 personer med type-2 diabetes med høy kardiovaskulær risiko (1). Pasienter fra 42 land og 590 studiesentre, inkludert åtte i Norge, ble randomisert til enten empagliflozin $10 \mathrm{mg}$, empagliflozin $25 \mathrm{mg}$ eller placebo, gitt i tillegg til standardbehandling. Ved start av studien benyttet $77 \%$ av pasientene statiner, $95 \%$ antihypertensiver og $83 \%$ acetylsalisylsyre. Primært endepunkt var død på grunn av kardiovaskulær hendelse eller et hjerteinfarkt eller hjerneslag som pasienten overlevde.

Etter en median oppfølgingstid på 3,1 år var det en lavere andel av pasienter på empagliflozin (10,5\%) enn på placebo $(12,1 \%)$ som nådde et primært endepunkt $(p=0,04)$. Forskjellen var særlig knyttet til en relativ risikoreduksjon for kardiovaskulær død på 38\% (absolutt risikoreduksjon $=2,1 \%, p<0,001)$. Det var ingen signifikante forskjeller for ikke-fatalt hjerteinfarkt eller ikke-fatalt hjerneslag. Den relative risikoen for sykehusinnleggelser for hjertesvikt var redusert med $35 \%$ (absolutt risikoreduksjon $=1,4 \%, p=0,0017)$ og totalmortalitet med $32 \%$ (absolutt risikoreduksjon $=2,6 \%, p<0,001)$. Genitale infeksjoner var vanligere ved bruk av empagliflozin, men de fleste av disse var milde og medførte sjelden behov for å avslutte behandlingen.

- Dette er en viktig og banebrytende studie, ettersom det er første gang et blodsukkersenkende middel har vist å redusere kardiovaskulære hendelser blant pasienter med type- 2 diabetes og etablert karsykdom, sier Odd Erik Johansen, som er lege, medisinsk direktør i legemiddelfirmaet Boehringer Ingelheim og en av medforfatterne. - Dette illustrerer viktigheten av å gjøre store og gode randomiserte studier.

Forfattergruppen håper nå at retnings-

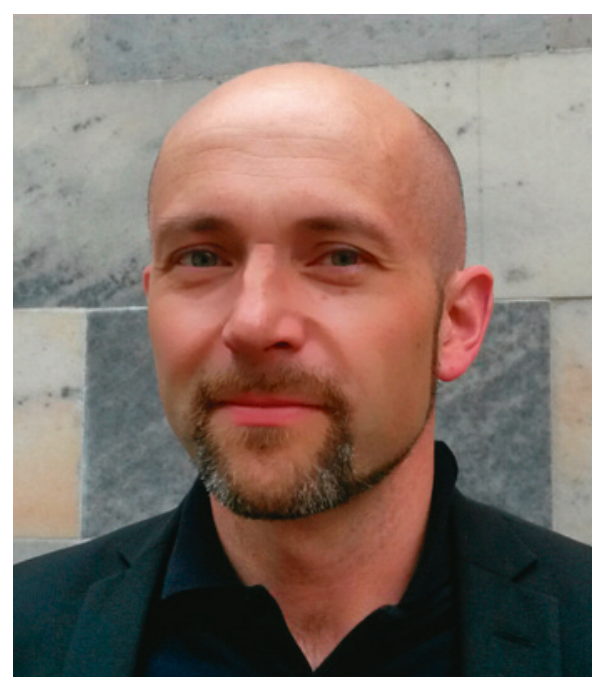

Odd Erik Johansen, artikkelens norske medforfatter. Foto: privat

linjer for behandling av diabetes vil endres som følge av studien.

\section{Samarbeid mellom industri og akademia}

Artikkelen er skrevet av leger, forskere og medlemmer av studiens styringskomité. Forfatterlisten besto av fem legeforskere fra Canada, USA og Tyskland, tre forskere fra Boehringer Ingelheim, som har utviklet empagliflozin, og fire personer som var sentrale i datainnsamling og dataanalyser. Samarbeidet kom i stand etter invitasjon fra legemiddelfirmaet for å studere kardiovaskulære effekter av empagliflozin. Et slikt samarbeid mellom industri og akademia er en veletablert samarbeidsform ved store behandlingsstudier som dette, og som også legemiddelmyndighetene oppfordrer til. Odd Erik Johansen hadde det medisinske ansvaret for gjennomføringen av studien globalt.

\section{Kaveh Rashidi}

Tidsskriftet

\section{Litteratur \\ 1. Zinman B, Wanner C, Lachin JM et al. Empagli- flozin, cardiovascular outcomes, and mortality in Type 2 diabetes. N Engl J Med 2015; 373: 2117-28.}

Ordforklaringer

Kardiovaskulær mortalitet: dødsfall som relateres til en kardiovaskulær hendelse.

Genitale infeksjoner: underlivsinfeksjoner, vanligvis soppinfeksjon.

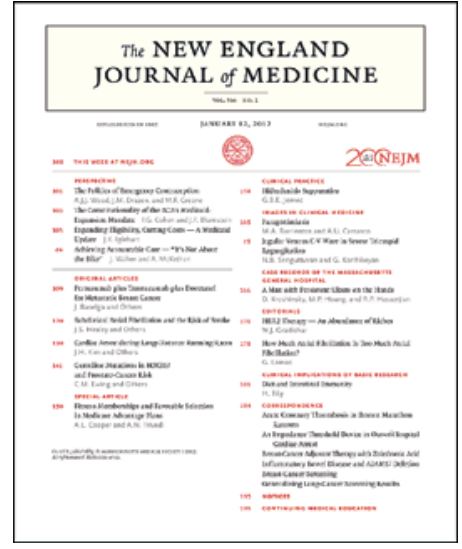

Studien ble publisert New England Journal of Medicine i september 2015 